\title{
Pembelajaran Tahfidz Alquran pada Anak Usia Dini
}

\author{
Abu Maskur \\ Universitas Indraprasta PGRI Jakarta, Indonesia \\ masykur_azizi@yahoo.co.id
}

\begin{abstract}
Abstrak:
Penelitian ini bertujuan untuk mengetahui pembelajaran tahfidz alquran di Taman Kanakkanak (TK) Roudlotul Qurro Cirebon. Metode yang digunakan dalam penelitian ini adalah metode kualitatif dengan teknik studi kasus dan observasi. Adapun hasil yang diperoleh dalam penelitian ini bahwa pembelajaran tahfidz alquran meliputi tiga kegiatan pokok, yaitu perencanaan, pelaksanaan dan penilaian. Perencanaan pembelajaran dilakukan sebelum tahun pelajaran dimulai melalui musyawarah guru dengan kepala sekolah. Pelaksanaan pembelajaran mencakup kegiatan awal (pendahuluan) yang diawali dengan sapaan salam, doa dan mengulang hafalan yang sudah dihafal sebelumnya. Kemudian kegiatan inti, yakni penyampaian materi tahfidz alquran dengan cara guru membacakan dan peserta didik mengikuti dan kemudian mengulang-ulang. Dan terakhir kegiatan penutup yang ditutup dengan evaluasi kecil-kecilan dan penyampaian materi yang akan dipelajari pada pertemuan berikutnya. Adapun penilaian terbagi ke dalam dua kategori, yaitu penilaian harian dan penilaian semesteran. Metode penilaian yang digunakan dalam pembelajaran tahfidz alquran dengan metode tasmi' dan musabaqah.
\end{abstract}

Kata Kunci: Pembelajaran, Tahfidz alquran, Anak Usia Dini

\begin{abstract}
:
This study aims to determine the learning of tahfidz alquran in kindergarten (Roudlotul Qurro) Cirebon. The method used in this research is a qualitative method with case study and observation techniques. The results obtained in this study that learning tahfidz the Koran includes three main activities, namely planning, implementation and assessment. Learning planning is carried out before the school year begins through teacher consultation with the school principal. The learning process includes an initial activity (introduction) which begins with greetings, prayers and repetition of memorization that has been memorized beforehand.
\end{abstract}


Then the core activity, namely the delivery of tahfidz alquran material by the way the teacher reads and students follow and then repeat. And finally the closing activity which was closed with a small evaluation and delivery of material to be studied at the next meeting. The assessment is divided into two categories, namely daily assessment and semester assessment. The assessment method used in learning the Koran tahfidz with the method of Tasmi and Musabaqah.

Keywords: Learning, Tahfidz Alquran, Early Childhood

\section{Pendahuluan}

Saat ini program tahfidz alquran menjadi program yang sedang populer dan sangat digemari di beberapa lembaga pendidikan baik negeri maupun swasta, baik formal maupun non formal. Hal ini bisa dibuktikan selain dengan banyaknya lembaga pendidikan tahfidz alquran yang didirikan seperti rumah tahfidz, wisma tahfidz dan sebagainya juga di sebagian lembaga pendidikan baik swasta maupun negeri yang menjadikan tahfidz alquran sebagai program unggulan.

Secara bahasa, istilah tahfidz alquran berasal dari dua kata, yaitu kata tahfidhz dan kata Alquran. Kata tahfidhz berasal dari Bahasa Arab yang artinya memelihara, menjaga dan menghafal. ${ }^{1}$ Dalam Kamus Besar Bahasa Indonesia, pengertian menghafal adalah berusaha meresapkan pikiran agar selalu ingat. ${ }^{2}$ Sedangkan menurut Abdul Aziz Abdul Rauf, menghafal Alquran adalah proses mengulang sesuatu baik dengan membaca atau mendengar. Pekerjaan apapun jika sering diulang, pasti menjadi hafal. ${ }^{3}$ Dengan demikian, menghafal Alquran adalah meresapkan huruf-huruf, ayat-ayat, dan surat-surat dalam Alquran ke dalam pikiran dengan cara mengulang-ulang baik dengan membaca atau mendengar yang tujuannya agar selalu ingat. Bagi kaum muslimin, mempelajari Alquran adalah hukumnya fardhu 'ain, yakni kewajiban yang harus dijalankan oleh masing-masing individu muslim. Selain sebagai kewajiban, kaum muslimin juga meyakini bahwa Alquran yang merupakan kalam Allah Swt. yang diturunkan kepada Nabi Muhammad Saw melalui perantara malaikat Jibril As adalah sebagai petunjuk atau huddan bagi manusia karena di dalamnya terdapat petunjuk-petunjuk bagi keselamatan manusia baik di dunia maupun di akhirat. Selain menjadi kewajiban setiap muslim,

\footnotetext{
${ }^{1}$ Mahmud Yunus. Kamus Arab-Indonesia. (Jakarta: Hidakarya Agung, 1990). hal. 105.

${ }^{2}$ Prima Tim Pena. Penilaian Hasil Proses Belajar Mengajar. (Bandung: Remaja Rosda Karya 1999) hal. 307.

${ }^{3}$ Abdul Rauf, Abdul Aziz. Kiat Sukses Menjadi Hafidhz Qur'an (Bandung: PT Syamil Cipta Media, 2004) hal. 49.
} 
mempelajari Alquran termasuk ibadah yang utama terlebih lagi jika mampu untuk menghafalkannya.

Ada beberapa keutamaan bagi siapa saja yang mampu untuk menghafalkannya setidaknya ada tiga keutamaan. Pertama, orang yang menghafal Alquran adalah orang-orang pilihan Allah Swt. karena menerima warisan dari Allah Swt. berupa kitab suci Alquran (QS. 35/32). Kedua, orang yang menghafal Alquran pada hari kiamat nanti akan memakaikan mahkota kepada kedua orang tuanya di mana cahaya mahkotanya lebih indah daripada cahaya matahari yang masuk ke rumah-rumah di dunia (HR. Abu Daud). Ketiga, menghafal Alquran adalah keistimewaan umat Islam karena Allah Swt. telah menjadikan umat terbaik di kalangan manusia dan memudahkannya untuk menjaga kitab-Nya, baik secara tulisan maupun hafalan. ${ }^{4}$ Dengan dorongan inilah banyak orang tua berlomba-lomba untuk menitipkan putra-putrinya ke lembaga pendidikan Islam yang memiliki program unggulan, yaitu tahfidz alquran dengan harapan kelak anaknya menjadi seorang penghafal Alquran.

Anak usia dini adalah anak berumur 0-6 tahun dengan pertumbuhan dan perkembangan yang pesat. Masa ini adalah masa yang tepat untuk menanamkan nilai-nilai kebaikan yang diharapkan dapat membentuk kepribadian anak. ${ }^{5}$ Masa ini menurut para pakar adalah masa keemasan (golden age), yakni masa yang sangat penting untuk mengoptimalkan pertumbuhan dan perkembangan anak, termasuk perkembangan daya hafalan karena secara mendasar sistem syaraf telah terbentuk. Anak pada masa usia dini memiliki daya ingat yang kuat terhadap apa yang ia dapat melalui pancaindranya sehingga informasi apa pun yang ia terima akan mudah dihafal dan dipraktikkan. Dengan demikian, program tahfidz alquran bisa diterapkan pada anak usia dini melalui program pembelajaran bagi anak usia dini, yaitu Taman Kanak-kanak.

Pembelajaran adalah segala upaya yang dilakukan oleh guru (pendidik) agar terjadi proses belajar pada diri siswa. Secara implisit, di dalam pembelajaran ada kegiatan memilih, menetapkan, dan mengembangkan metode untuk mencapai hasil pembelajaran yang diinginkan. ${ }^{6}$ Sedangkan menurut Hidayatullah, pembelajaran adalah suatu aktivitas yang dengan sengaja untuk memodifikasi berbagai kondisi yang diarahkan untuk tercapainya suatu tujuan, yaitu tercapainya tujuan kurikulum. ${ }^{7}$ Dengan demikian, pembelajaran tahfidz alquran adalah upaya yang sengaja dilakukan oleh seorang guru, kiai, ustaz atau instruktur tahfidz untuk memodifikasi berbagai kondisi yang diarahkan untuk tercapainya tujuan dari tahfidz alquran.

\footnotetext{
${ }^{4}$ Hasan. Menghafal Alquran Itu Mudah (Jakarta: Pustaka At-Tazkia, 2008) hal.10.

${ }^{5}$ Muhammad Fadilah. Desain Pembelajaran PAUD (Yogyakarta: Ar-Ruz Media, 2012) hal. 19.

${ }^{6}$ M. Sobry Sutikno. Belajar dan Pembelajaran (Bandung: Prospect, 2009) hal. 32.

${ }^{7}$ Hidayatullah. Media Pembelajaran Pendidikan Agama Islam (Jakarta: Thariqi Press 2008) hal. 6.
} 
Sedangkan Taman Kanak-kanak (TK) adalah salah satu bentuk satuan PAUD pada jalur pendidikan formal yang menyelenggarakan program pendidikan bagi anak berusia 4 tahun sampai dengan 6 tahun dengan prioritas usia 5 dan 6 tahun. $^{8}$

Berdasarkan Peraturan Menteri Pendidikan Nasional Nomor 58 Tahun 2009 tentang Standar Pendidikan Anak Usia Dini, menyebutkan penyelenggaraan Pendidikan Anak Usia Dini mempunyai standar isi, proses, dan penilaian dalam pelaksanaan pembelajarannya. Adapun standar isi, proses, dan penilaian tersebut meliputi perencanaan, pelaksanaan dan penilaian program yang dilaksanakan secara terintegrasi/terpadu sesuai dengan kebutuhan anak. Salah satu faktor keberhasilan dari suatu pembelajaran adalah kemampuan guru yang meliputi penguasaan terhadap bidang pengetahuan yang akan diajarkan, pembuatan persiapan tertulis (RPP/Silabus), dan pelaksanaan pengajaran. Guru sebagai pengelola kelas perlu memiliki kecakapan sebagai perancang pembelajaran, pengelola pembelajaran, dan penilai prestasi belajar siswa. ${ }^{9}$ Dengan demikian, pembelajaran tahfidz alquran pada anak usia dini terdiri dari perencanaan, pengelolaan pembelajaran, dan penilaian hasil belajar.

Pertama, perencanaan. Perencanaan adalah hubungan antara apa yang ada sekarang (what is) dengan bagaimana seharusnya ( what should be) yang bertalian dengan kebutuhan, penentuan tujuan, prioritas program dan alokasi sumber. ${ }^{10}$ Jamil Suprihatiningrum menyebutkan proses pembelajaran dimulai dari analisis situasi dan kebutuhan sebagai dasar pengembangan rencana pembelajaran sehingga membantu guru mengorganisasikan materi. ${ }^{11}$ Melalui perencanaan pembelajaran guru dapat mengetahui tujuan yang ingin dicapai dalam pembelajaran serta caracara yang dilakukan untuk mencapainya. Perencanaan berarti menyusun langkah-langkah penyelesaian suatu masalah atau pelaksanaan suatu pekerjaan yang terarah pada pencapaian tujuan tertentu. ${ }^{12}$ Masnur Muslich menyebutkan komponen terpenting pada perencanaan pembelajaran diarahkan pada lima aspek, yaitu perumusan tujuan pembelajaran, pemilihan dan pengorganisasian materi ajar, pemilihan sumber belajar/media pembelajaran, skenario/kegiatan pembelajaran dan penilaian hasil belajar. ${ }^{13}$ Dalam pembelajaran tahfidz alquran perlu dirumuskan tujuan pembelajaran yang disesuaikan dengan kompetensi dasar meliputi target hafalan dan jangka waktunya. Pemilihan dan pengorganisasian materi yang mengacu pada tujuan pembelajaran yang ingin dicapai, jika tujuan pembelajarannya juz 30

\footnotetext{
${ }^{8}$ Kemendikbud. Petunjuk Teknis Penyelenggaraan Taman Kanak-Kanak (Jakarta: Kemendikbud 2015) hal. 3.

${ }^{9}$ Jamil Suprihatiningrum. Strategi Pembelajaran (Yogyakarta: Ar-Ruzz Media 2014) hal. 107.

${ }^{10}$ Muhammad Afandi \& Badarudin. Perencanaan Pembelajaran Di Sekolah Dasar (Bandung: Alfabeta, 2011) hal. 2.

${ }^{11}$ Jamil Suprihatiningrum. Strategi Pembelajaran, hal. 111.

${ }^{12}$ Hadari Nawawi. Metode Penelitian Deskriptif (Yogyakarta: Gajah Mada University Press. 1983) hal. 16

${ }^{13}$ Masnur Muslich. Pendidikan Anak Usia Dini dalam Islam (Yogyakarta: Pustaka Pelajar 2007) hal. 67.
} 
maka tentunya pemilihan materinya juga tentang juz 30 bukan selainnya. Pemilihan sumber belajar/media pembelajaran tahfidz alquran harus disesuaikan dengan tujuan pembelajaran dan materi pembelajaran, baik berupa mushaf Alquran, rekaman bacaan Alquran atau talaqqi (bertemu langsung) dengan guru tahfidz. Kemudian merencanakan kegiatan tahfidz alquran yang meliputi strategi dan metode yang akan digunakan dalam pembelajaran tahfidz alquran. Dan terakhir adalah penilaian yang berpatokan kepada tujuan pembelajaran. Perencanaan ini dituangkan dalam bentuk rencana belajar yang disusun oleh guru atau biasa dikenal dengan rencana kegiatan harian $(\mathrm{RKH})$.

Kedua, pelaksanaan. Pelaksanaan pembelajaran adalah proses yang diatur sedemikian rupa menurut langkah-langkah tertentu agar pelaksanaan mencapai hasil yang diharapkan. ${ }^{14}$ Kegiatan pembelajaran merupakan suatu hal yang sangat penting dalam kegiatan pendidikan. Pada tahap inilah materi yang menjadi tujuan pendidikan disampaikan atau diberikan kepada peserta didik. ${ }^{15}$ Pelaksanaan pembelajaran adalah suatu kegiatan yang bernilai edukatif mewarnai interaksi yang terjadi antara guru dan siswa. Interaksi yang bernilai edukatif dikarenakan pelaksanaan pembelajaran yang dilakukan diarahkan untuk mencapai tujuan tertentu yang telah dirumuskan sebelum pelaksanaan pembelajaran dimulai. ${ }^{16}$ Tujuan pembelajaran tahfidz alquran adalah agar anak mampu untuk menghafal Alquran dengan target yang telah direncanakan sehingga komponen-komponen dalam pembelajaran dilaksanakan dalam rengka mendukung kemampuan anak dalam menghafal Alquran. Kegiatan ini meliputi pengelolaan kelas, penggunaan media dan sumber belajar, serta strategi pembelajaran. Syaiful Bahri Djamarah mengatakan bahwa pengelolaan kelas adalah keterampilan guru menciptakan dan memelihara kondisi belajar yang optimal dan mengembalikannya bila terjadi gangguan dalam proses interaksi edukatif. ${ }^{17}$ Sedikitnya ada tujuh hal yang harus diperhatikan untuk menciptakan iklim pembelajaran yang kondusif dan menyenangkan, yaitu ruang belajar, pengaturan sarana belajar, susunan tempat duduk, penerangan, suhu, pemanasan sebelum materi yang akan dipelajari, dan bina suasana dalam belajar. ${ }^{18}$ Media pembelajaran adalah segala sesuatu yang dapat digunakan untuk membantu proses pembelajaran, dalam artian dapat memudahkan seorang pengajar untuk menyampaikan materi pembelajaran. Sedangkan sumber belajar adalah segala sesuatu yang dapat dijadikan sebagai bahan pembelajaran. Selain pengelolaan kelas dan penggunaan media dan sumber belajar, komponen penting pelaksanaan

\footnotetext{
${ }^{14}$ Nana Sudjana. Penilaian Hasil Proses Belajar Mengajar (Bandung: Remaja Rosda Karya, 2010) hal. 136.

${ }^{15}$ Muhammad Fadillah. Desain Pembelajaran PAUD (Yogyakarta: Ar-Ruz Media, 2012) hal. 131.

${ }^{16}$ Syaiful Bahri dan Aswan Zain. Strategi Belajar Mengajar (Jakarta: Rineka Cipta, 2010) hal. 1.

${ }^{17}$ Syaiful Bahri Djamarah. Guru dan Anak Didik dalam Interaksi Edukatif. (Jakarta: Rineka Cipta, 2000) hal. 145.

18 Abdul Majid. Perencanaan Pembelajaran.. (Bandung: PT Remaja Rosda Karya, 2012) hal. 165.
} 
pembelajaran lainnya adalah strategi pembelajaran. Strategi pembelajaran adalah cara-cara yang akan dipilih atau digunakan oleh seorang pengajar dalam menyampaikan materi pembelajaran sehingga tujuan pembelajaran dapat tercapai secara optimal, tanpa strategi maka tujuan pembelajaran tidak dapat tercapai secara optimal. Dalam pelaksanaan pembelajaran tahfidz alquran pun perlu memperhatikan ketiga hal tersebut, yaitu pengelolaan kelas, penggunaan media dan sumber belajar serta penggunaan strategi pembelajaran agar pelaksanaan pembelajaran dapat terlaksana dengan baik dan tentunya tujuan dari pembelajaran tahfidz alquran dapat tercapai secara optimal.

Ketiga, penilaian hasil belajar. Penilaian adalah suatu proses atau kegiatan yang sistematis dan berkesinambungan untuk mengumpulkan informasi tentang proses dan hasil belajar peserta didik dalam rangka membuat keputusan-keputusan berdasarkan kriteria dan pertimbangan tertentu. ${ }^{19}$ Hasil belajar adalah kemampuan-kemampuan yang diperoleh peserta didik setelah proses pembelajaran atau setelah menerima pengalaman belajar. Dalam pembelajaran, penilaian hasil belajar sangat penting sebagai bahan bagi pendidik untuk melakukan peningkatan kualitas pembelajaran sekaligus sebagai motivasi bagi peserta didik. Penilaian hasil belajar bisa dilihat dari tiga aspek, yaitu kognitif, psikomotorik dan afektif. Aspek kognitif meliputi pengetahuan, penerapan, pemahaman, penerapan, analisis, sintesis, dan evaluasi. Aspek psikomotorik meliputi persepsi, kesiapan, gerakan terbimbing, gerakan terbiasa, gerakan kompleks dan penyesuaian pola gerakan serta kreativitas. Sedangkan aspek afektif meliputi penerimaan, partisipasi, penilaian, atau penentuan sikap, organisasi dan pembentukan pola hidup. Dalam pembelajaran tahfidz alquran penilaian bisa dilakukan dengan berbagai cara, di antaranya dengan tes hafalan secara berurutan baik ayat maupun suratnya, tes hafalan secara acak ayat dan suratnya atau yang dikenal dengan sistem musabaqah, tes hafalan dengan menuliskan ayat atau surat yang telah dihafal ke dalam sebuah kertas, dan sebagainya sehingga seorang pengajar tahfidz alquran bisa mendapatkan gambaran tentang layak atau tidaknya penghafal Alquran tersebut diluluskan dan juga seorang pengajar dapat meningkatkan kualitas pembelajaran tahfidz alquran agar ke depan tujuan dari pembelajaran tahfidz alquran dapat tercapai secara optimal.

Taman Kanak-kanak Roudlotul Qurro adalah salah satu lembaga pendidikan anak usia dini di Kota Cirebon yang menerapkan program tahfidz alquran sebagai program khusus dan unggulan. Lembaga ini didirikan pada tahun 2010 di bawah naungan Yayasan Roudlotul Qurro yang diketuai oleh Ust. Afandi salah seorang Qari yang pernah mewakili Provinsi Jawa Barat

${ }^{19}$ Asrul, dkk. Evaluasi Pembelajaran. (Bandung: Cipta Pustaka, 2015) hal. 2 
dalam Musbaqah Tilawatil Qur'an (MTQ) di Aceh tahun 1984. Adapun target hafalan dalam program tahfidz alquran di lembaga tersebut adalah juz 30 (juz 'amma) yang harus dicapai selama dua semester. Dengan demikian penelitian ini bertujuan untuk mengetahui proses pembelajaran tahfidz alquran di Taman Kanak-kanak Roudlotul Qurro Kota Cirebon yang mencakup perencanaan pembelajaran, pelaksanaan pembelajaran dan penilaian hasil belajar tahfidz alquran.

Metode yang digunakan dalam penelitian ini adalah metode kualitatif. Metode penelitian kualitatif adalah metode penelitian yang berlandaskan pada filsafat pos-positivisme, digunakan untuk meneliti pada kondisi obyek yang alamiah, (sebagai lawannya adalah eksperimen) di mana peneliti adalah sebagai instrumen kunci, pengambilan sampel sumber data dilakukan secara purposive dan snowbaal, teknik pengumpulan dengan triangulasi (gabungan), analisis data bersifat induktif/kualitatif, dan hasil penelitian kualitatif lebih menekankan makna daripada generalisasi. ${ }^{20}$ Data dalam penelitian ini adalah berbagai informasi dan keterangan yang diperoleh kepala sekolah dan guru. Ada pun data yang diperoleh merupakan hasil dari studi kasus dan observasi langsung di TK Roudlotul Qurro Kota Cirebon. Teknik pengumpulan data dalam penelitian ini dengan triangulasi (gabungan) dan analisis data dalam penelitian ini bersifat induktif.

\section{Perencanaan Pembelajaran Tahfidz Alquran}

Seperti yang telah dijelaskan di atas bahwa perencanaan pembelajaran diarahkan pada lima aspek, yaitu perumusan tujuan pembelajaran, pemilihan dan pengorganisasian materi ajar, pemilihan sumber belajar/media pembelajaran, skenario/kegiatan pembelajaran dan penilaian hasil belajar. Perencanaan ini dilakukan sebelum tahun pelajaran dimulai melalui musyawarah guru dengan melakukan analisis kebutuhan peserta didik, harapan masyarakat dan tentunya tujuan daripada lembaga pendidikan Roudlotul Qurro yang mempunyai misi dalam pengembangan Alquran. Berdasarkan hasil wawancara dengan kepala sekolah diketahui bahwa tujuan pembelajaran Tahfidz alquran adalah tercapainya target hafalan juz 30 dalam 1 tahun dengan rincian bahwa kelompok A target hafalan dimulai dari surat Al-Lail sampai dengan surat An-Nas (23 surat) dan kelompok B target hafalan dimulai dari surat An-Naba sampai dengan surat Asy-Syams (14 surat). Meskipun tidak semua peserta didik mampu untuk menghafal semua surat-surat tersebut, setidaknya memperkenalkan dan mengakrabkan mereka tentang surat-surat pendek tersebut agar kelak setelah selesai belajar di TK mempunyai dasar

\footnotetext{
${ }^{20}$ Sugiyono. Metode Penelitian Pendidikan (Bandung: Alfabeta, 2011) hal. 15. 
hafalan. Sumber belajar atau media pembelajaran yang digunakan dalam proses pembelajaran adalah mushaf Alquran dengan rasm 'Usmani secara seragam, artinya semua peserta didik harus menggunakan mushaf yang sama dalam satu kelas dengan alasan agar mempermudah untuk menghafal terutama target hariannya. Selain mushaf Alquran, sumber belajar yang digunakan adalah rekaman murattal Alquran yang digunakan untuk membantu peserta didik dalam melantunkan ayat-ayat Alquran dengan lagu yang seragam. Skenario atau kegiatan pembelajaran tahfidz alquran dibagi menjadi dua kegiatan, yaitu kegiatan menambah hafalan dan mengulang hafalan. Kegiatan tersebut merupakan kegiatan yang paling penting dalam pembelajaran tahfidz alquran karena proses penghafalan Alquran harus diikuti dengan proses pengulangan hafalan. Kegiatan tersebut direncanakan berdasarkan kebiasaan guru dalam mengajar di kelas, baik terkait strateginya maupun metodenya. Adapun penilaian hasil belajar direncanakan oleh guru setelah selesai semua kegiatan pembelajaran dan setelah target hafalan tercapai.

\section{Kegiatan Pembelajaran Tahfidz Alquran}

Kegiatan pembelajaran tahfidz alquran dilaksanakan setiap hari Senin sampai dengan Kamis pukul 08.00-08.30 dan khusus untuk hari Jum'at adalah kegiatan tasmi', yaitu mendengarkan hafalan-hafalan peserta didik dan seluruh peserta didik wajib hadir dan wajib di-tasmi' hafalannya. Kegiatan tasmi' dilaksanakan setiap hari Jum'at pukul 08.00-08.30. Kegiatan pembelajaran tahfidz alquran ini meliputi tiga kegiatan pokok, yaitu pembukaan, kegiatan inti dan kegiatan penutup.

Pertama, pembukaan. Kegiatan ini diawali sapaan salam dan menanyakan kabar kepada seluruh peserta didik. Kemudian dilanjutkan dengan pengecekan kehadiran, kerapian, ketertiban, dan perlengkapan pelajaran dan dilanjutkan dengan pembacaan doa' belajar. Setelah seluruh peserta didik duduk tertib dan rapi, guru meminta kepada peserta didik untuk mengulang hafalan yang telah dihafal sebelumnya dan dibaca bersama-sama. Kegiatan ini dilakukan untuk menggali pengetahuan atau hafalan yang dimiliki oleh peserta didik sekaligus mengevaluasi pembelajaran yang telah dilakukan sebelumnya agar mempunyai gambaran terhadap pembelajaran yang akan dilakukan setelahnya.

Kedua, kegiatan inti. Setelah menyiapkan peserta didik untuk belajar dan mengulang materi hafalan yang telah diajarkan pada pertemuan terakhir, kegiatan selanjutnya adalah menyampaikan materi baru kepada peserta didik. Penyampaian materi dilakukan dengan mendiktekan ayat per-ayat secara langsung kepada peserta didik dan peserta didik mendengarkan dan kemudian menirukan bacaan yang disampaikan oleh guru hingga lancar. 
Setelah peserta didik dapat menirukan bacaan guru dengan baik, kemudian guru meminta peserta didik untuk mengulang kembali bacaan yang telah dihafalnya hingga peserta didik hafal dengan baik. Adapun targetan hafalan dalam setiap pembelajaran adalah 1-6 ayat itu pun tergantung karakter dari sebuah ayat, jika ayatnya pendek mungkin bisa lebih dari 6 ayat sebaliknya jika ayatnya panjang mungkin bisa kurang dari 6 ayat, yang jelas targetan hafalan sudah dipetakan oleh guru. Setelah semua peserta didik dirasa cukup hafal, kemudian peserta didik diminta untuk menyetorkan hafalannya masing-masing kepada guru dan guru menyimak serta mencatat hafalan tersebut ke dalam buku laporan tahfidz alquran. Berdasarkan wawancara dengan kepala sekolah diperoleh keterangan bahwa kriteria yang harus dimiliki oleh guru tahfidz alquran adalah 1) lulusan pondok pesantren 2) hafal Alquran sekurangkurangnya juz 30 3) mahir dalam membaca Alquran sesuai dengan kaidah tajwid, makharijul huruf, dan shifatul huruf-nya 4) memahami aneka ragam karakter peserta didik. Selain itu ditemukan juga bahwa cara yang mungkin tepat untuk pembelajaran tahfidz alquran pada anak usia dini adalah dengan mendiktekan bacaan kemudian peserta didik mendengarkan dan menirukan bacaan guru.

Ketiga, penutup. Kegiatan ini dapat dilakukan dengan cara menanyakan kembali materi yang sudah dihafal dalam kegiatan inti. Dalam kegiatan ini juga bisa disampaikan tentang materi hafalan yang akan disampaikan pada pertemuan selanjutnya dengan tujuan agar para peserta didik bisa mempersiapkan diri di rumah. Dan terakhir adalah pembiasaan doa penutup majelis dan sedikit pesan moral kepada peserta didik.

\section{Penilaian Hasil Belajar Tahfidz Alquran}

Penilaian hasil belajar tahfidz alquran dibagi menjadi dua kategori, yaitu penilaian harian dan penilaian akhir semester. Penilaian harian dilakukan dengan pengamatan terhadap perkembangan hafalan peserta didik termasuk kelancaran dan kefasihan peserta didik dalam membaca Alquran, peserta didik dibimbing dan diberikan arahan oleh guru jika hafalannya kurang lancar dan bacaannya kurang sesuai dengan tajwid dan makharijul huruf-nya. Selain penilaian harian, juga dilakukan kegiatan tasmi' meskipun bukan bagian dari penilaian tetapi kegiatan ini menjadi sangat penting terutama dalam rangka untuk menopang hafalan dan membantu membiasakan diri dalam membacakan hafalannya di hadapan khalayak dengan tanpa mushaf Alquran. Adapun penilaian akhir semester terbagi ke dalam dua metode. Pertama metode tasmi', yaitu metode di mana peserta didik membacakan ayat-ayat atau surat-surat yang telah dihafal selama satu semester satu persatu secara berurutan dan guru menyimak dan melakukan penilaian. Metode penilaian ini bertujuan untuk memperkuat hafalan secara 196 | IQ (Ilmu Al-qur'an): Jurnal Pendidikan Islam | Volume 1 No.02 2018 
berurutan. Kedua metode musabaqah, yaitu metode di mana guru membacakan ayat atau surat secara acak kemudian peserta didik melanjutkan ayat atau surat tersebut dan guru melakukan penilaian. Metode ini bertujuan untuk menguji kekuatan dan kejelian hafalan peserta didik.

Penilaian hasil belajar baik harian maupun semesteran didokumentasikan dalam buku laporan perkembangan tahfidz alquran yang harus dibawa peserta didik setiap hari. Buku laporan ini bertujuan untuk memberikan informasi perkembangan tahfidz alquran bagi guru dan orang tua. Guru akan memberikan catatan jika ada sesuatu yang ingin diinformasikan terkait tahfidz alquran kepada peserta didik termasuk kepada orang tua.

\section{Kesimpulan}

Pembelajaran tahfidz alquran di TK Roudlotul Qurro Kota Cirebon terdiri dari kegiatan perencanaan, pelaksanaan, dan penilaian hasil belajar. Perencanaan dilakukan sebelum tahun pelajaran dimulai melalui musyawarah guru dengan melakukan analisis kebutuhan peserta didik, harapan masyarakat dan tentunya tujuan daripada lembaga yakni tercapainya target hafalan juz 30. Pelaksanaan pembelajaran meliputi tiga kegiatan pokok yakni pendahuluan, kegiatan inti dan kegiatan penutup. Kegiatan awal (pendahuluan) dilakukan dengan mempersiapkan peserta didik untuk belajar, kemudian berdoa dan mengulang hafalan yang sudah dihafal (muraja'ah). Kegiatan inti dilaksanakan dengan penyampaian materi tahfidz alquran oleh guru dan peserta didik dibimbing untuk menghafalkan materi hafalan yang telah direncanakan. Sedangkan kegiatan penutup dilakukan dengan evaluasi kecil-kecilan terhadap hafalan dan penyampaian materi tahfidz alquran yang akan dihafal pada pertemuan selanjutnya. Penilaian hasil belajar dibagi menjadi dua kategori, yakni penilaian harian dan penilaian semesteran. Adapun metode penilaian terbagi menjadi dua, yaitu metode tasmi' dan musabaqah. 
Abu Maskur

\section{Daftar Pustaka}

Abdul Rauf, Abdul Aziz. 2004. Kiat Sukses Menjadi Hafidhz Qur'an. Bandung: PT Syamil Cipta Media.

Afandi, Muhammad dan Badarudin. 2011. Perencanaan Pembelajaran Di Sekolah Dasar. Bandung: Alfabeta.

Asrul, dkk. 2015. Evaluasi Pembelajaran. Bandung: Cipta Pustaka.

Bahri, Syaiful dan Zain, Aswan. 2010. Strategi Belajar Mengajar. Jakarta: Rineka Cipta.

Djamarah, Syaiful Bahri. 2000. Guru dan Anak Didik dalam Interaksi Edukatif. Jakarta: Rineka Cipta.

Fadilah, Muhammad. 2012. Desain Pembelajaran PAUD. Yogyakarta: Ar-Ruz Media.

Hamam, Hasan Bin Ahmad. 2008. Menghafal Alquran Itu Mudah. Jakarta: Pustaka AtTazkia.

Hidayatullah. 2008. Media Pembelajaran Pendidikan Agama Islam. Jakarta: Thariqi Press.

Kementrian Pendidikan dan Kebudayaan. 2015. Petunjuk Teknis Penyelenggaraan Taman Kanak-Kanak. Jakarta: Kemendikbud

Majid, Abdul. 2012. Perencanaan Pembelajaran. Bandung: PT Remaja Rosda Karya.

Muslich, Masnur. 2007. Pendidikan Anak Usia Dini dalam Islam. Yogyakarta: Pustaka Pelajar.

Prima Tim Pena. 1999. Kamus Besar Bahasa Indonesia. Jakarta: Gita Media Press.

Sudjana, Nana. 2010. Penilaian Hasil Proses Belajar Mengajar. Bandung: Remaja Rosda Karya.

Sugiyono. 2011. Metode Penelitian Pendidikan. Bandung: Alfabeta.

Suprihatiningrum, Jamil. 2014. Strategi Pembelajaran. Yogyakarta: Ar-Ruzz Media.

Sutikno, M. Sobry. 2009. Belajar dan Pembelajaran. Bandung: Prospect.

Yunus, Mahmud. 1990. Kamus Arab-Indonesia. Jakarta: Hidakarya Agung. 